\title{
GAMBARAN TINGKAT PENGETAHUAN REMAJA PUTRI TENTANG ANEMIA DI TABANAN
}

\author{
Hesteria Friska Armynia Subratha ${ }^{1,2}$ Kadek Sri Ariyanti ${ }^{1,2}$ \\ ${ }^{1}$ Program Studi DIII Kebidanan, ${ }^{2}$ Sekolah Tinggi Ilmu Kesehatan Advaita Medika Tabanan \\ Korespodensi penulis:hesteria.friska@yahoo.com
}

\begin{abstract}
Abstrak
Latar belakang dan tujuan: Anemia banyak terjadi pada masyarakat terutama pada remaja dan ibu hamil. Anemia pada remaja putri sampai saat ini masih cukup tinggi, menurut (WHO, 2015), prevalensi anemia dunia berkisar 50-80\%. Prevalensi anemia pada remaja putri (usia 15-19 tahun) sebesar 26,5\%, dan pada wanita subur sebesar 26,9\% (Kemenkes RI, 2015). Penelitian ini bertujuan untuk mengetahui gambaran tingkat pengetahuan remaja putri tentang anemia pada remaja di Tabanan.

Metode: Penelitian survei cross sectional dilakukan pada 137 dari kelas XI dan XII di SMA Negeri 1 Marga Tabanan. Teknik pengambilan sampel menggunakan simple random sampling.

Hasil: Hasil penelitian menunjukkan tingkat pengetahuan remaja putri tentang anemia pada remaja di SMA Negeri 1 Marga kategori pengetahuan baik sebanyak 121 responden $(88,3 \%)$, dan pengetahuan cukup sebanyak 16 responden $(11,7 \%)$.

Simpulan: Remaja diharapkan untuk meningkatkan pengetahuan dan wawasan mengenai kesehatan resproduksi remaja, sehingga dapat mencegah terjadinya anemia pada remaja..
\end{abstract}

Kata kunci : Anemia, Pengetahuan, Remaja

\section{Pendahuluan}

Anemia didefinisikan sebagai konsentrasi hemoglobin yang rendah dalam darah (WHO, 2015). Hemoglobin yaitu protein yang membawa oksigen keseluruh jaringan tubuh. Ketika seseorang tidak memiliki cukup sel darah merah atau jumlah hemoglobin dalam darah rendah maka tubuh tidak bisa mendapatkan oksigen sesuai kebutuhannya sehingga orang tersebut akan merasa lelah atau menderita gejala lainnya (Fikawati.dkk, 2017).

Remaja putri pada umumnya memiliki kebiasaan makan tidak sehat. Antara lain kebiasaan tidak makan pagi, malas minum air putih, diet tidak sehat karena ingin langsing (mengabaikan sumber protein, karbohidrat, vitamin dan mineral), kebiasaan ngemil makanan rendah gizi dan makanan siap saji. Hal tersebut menyebabkan remaja tidak mampu memenuhi keanekaragaman zat makanan yang dibutuhkan oleh tubuhnya untuk proses sintesis pembentukan hemoglobin $(\mathrm{Hb})$. Bila hal ini terjadi dalam jangka yang lama akan menyebabkan kadar $\mathrm{Hb}$ terus berkurang dan menyebabkan anemia (Suryani, 2015).

Anemia defisiensi besi merupakan anemia yang sering menjadi masalah pada remaja, karena kebutuhan zat besi yang tinggi untuk pertumbuhan. Remaja yang mengalami anemia biasanya sering pusing, cepat merasa lelah, tidak bertenaga atau bergairah dalam beraktivitas. Remaja putri menjadi rentan terhadap anemia sebab remaja putri mengalami siklus menstruasi. Ketidakseimbangan zat gizi juga menjadi penyebab anemia pada remaja. Remaja putri biasanya sangat memperhatikan bentuk tubuh, sehingga banyak yang membatasi konsumsi makanan dan banyak pantangan terhadap makanan (Budiman, 2016).

Anemia banyak terjadi pada masyarakat terutama pada remaja dan ibu hamil. Anemia pada remaja putri sampai saat ini masih cukup tinggi, menurut (WHO, 2015), 
prevalensi anemia dunia berkisar 50-80\%. Prevalensi anemia pada remaja putri (usia 1519 tahun) sebesar $26,5 \%$, dan pada wanita subur sebesar 26,9\% (Kemenkes RI, 2015).Tahun 2015 prevalensi anemia pada remaja putri di Indonesia yaitu sebesar $18,22 \%$. Sementara target dari Kementerian Kesehatan adalah sebesar 30\%. Itu artinya masih banyak terdapat remaja yang menderita anemia khususnya usia 15-21 tahun (Kemenkes RI, 2015).

Menurut data Survei Kesehatan Rumah Tangga (SKRT) tahun 2014 menyatakan bahwa prevalensi anemia pada balita sebesar $40,5 \%$, ibu hamil sebesar $50,5 \%$, ibu nifas sebesar $45,1 \%$, remaja putri usia 10 -18 tahun sebesar 57,1\% dan usia $19-45$ tahun sebesar $39,5 \%$. Wanita mempunyai risiko terkena anemia paling tinggi terutama pada remaja putri. Berdasarkan Data Riskesdas tahun 2016 di Provinsi Bali, prevalensi anemia pada remaja sebanyak 27,1\%. Hal ini menunjukkan bahwa masalah anemia khususnya pada wanita masih cukup tinggi (Kemenkes RI, 2014).

Anemia disebabkan oleh beberapa hal antara lain, seperti asupan makanan yang rendah zat besi atau zat besi yang terdapat terdalam makanan terdapat dalam bentuk yang sulit untuk diserap. Dan saat kehilangan darah tubuh perlu memproduksi sel darah merah lebih banyak dari biasanya, sehingga kebutuhan zat besi juga ikut meningkat. Saat simpanan zat besi dalam tubuh sudah habis dan penyerapan zat besi pada makanan sedikit, tubuh akan mulai memproduksi sel darah merah lebih sedikit dan mengandung hemoglobin yang lebih sedikit pula. Hal inilah yang akhirnya menyebabkan anemia gizi besi, yang merupakan penyebab anemia yang paling sering terjadi (Sandra dkk, 2017)

Penyebab utama anemia dapat dikategorikan dalam kategori rendah: kekurangan, atau produksi sel darah merah yang abnormal, pemecahan sel darah merah yang berlebihan, dan hilangnya sel darah merah secara berlebihan. Penyebab yang berkaitan dengan kurang gizi, dihubungkan pada asupan makanan, kualitas makanan, sanitasi dan perilaku kesehatan, kondisi lingkungan sekitar, akses kepada pelayanan kesehatan, dan kemiskinan.

Beberapa faktor lain yang diduga mempengaruhi status anemia remaja putri diantaranya adalah pengetahuan remaja tentang anemia, dan pola makan remaja. Kurangnya pengetahuan remaja tentang anemia menyebabkan remaja sangat rentan terhadap perilaku makan yang negatif sehingga remaja putri merupakan salah satu kelompok yang rawan menderita anemia. Pengetahuan merupakan resultan dari akibat proses penginderaan terhadap suatu objek tertentu. Perilaku kesehatan seseorang atau masyarakat ditentukan oleh niat orang terhadap objek kesehatan, dukungan dari masyarakat sekitarnya, informasi tentang kesehatan, kebebasan individu untuk bertindak dan situasi yang memngkinkan untuk bertindak (Soekidjo, 2010). Faktor lain yang diduga mempengaruhi anemia pada remaja putri adalah tidak mengkonsumsi TTD (Tablet Tambah Darah).

Hasil penelitian tingkat pengetahuan remaja putri tentang anemia pada siswi kelas IX di SMP Negeri 2 Tawangmangu pada kategori pengetahuan baik sebanyak 11 responden (22\%), pengetahuan cukup sebanyak 28 responden $(56 \%)$ dan pengetahuan kurang sebanyak 11 responden (22\%) (Handayani, 2015).

Berdasarkan survei pendahuluan yang dilakukan di SMA Negeri 1 Marga, yang dilakukan terhadap 10 siswi didapatkan hasil $60 \%$ siswi yang belum mengerti tentang anemia, sedangkan $40 \%$ siswi sudah mengerti tentang pengertian anemia. Berdasarkan deskripsi di atas, penulis tertarik untuk melakukan penelitian mengenai gambaran tingkat pengetahuan remaja putri tentang anemia pada remaja di SMA Negeri 1 Marga.

\section{Metode Penelitian}

Peneliti menggunakan penelitian kuantitatif dengan pendekatan cross sectional dimana peneliti mempelajari kejadian secara serentak pada individu dan populasi tunggal pada satu saat atau periode tertentu. Populasi 
dalam penelitian ini adalah semua siswi kelas XI dan XII di SMA Negeri 1 Marga dengan jumlah 208 orang. Teknik sampel yang digunakan dalam penelitian ini adalalah simple random sampling. Setelah dimasukkan rumus didapatkan jumlah sampel 137 orang.

Dalam melakukan pengumpulan data, penelitian ini menggunakan alat pengumpulan data berupa kuesioner. Kuesioner ini telah dilakukan uji validitas. Setelah didapatkan hasil bahwa kuesioner ini valid dan reliabel maka kuesioner ini dapat digunakan dalam penelitian. Teknik analisis dalam penelitian ini adalah analisis univariat.

\section{Hasil dan Pembahasan}

Berdasarkan tabel 1 dapat diketahui tentang karakteristik responden yaitu karakteristik responden kelas paling banyak yaitu pada kelas XII yaitu sebesar 53,3\%, pada karakteristik umur paling banyak pada umur 17 tahun yaitu 51,1\%. Karakteristik responden pekerjaan orang tua paling banyak yaitu tidak PNS yaitu sebesar $84,7 \%$, dan penghasilan orang tua paling banyak yaitu > UMK yaitu $64,2 \%$. Karakteristik responden tempat tinggal yaitu sebanyak $100 \%$, pada sumber informasi tentang anemia paling banyak yaitu pada tenaga kesehatan sebesar $41,6 \%$, dan mitos tentang anemia yaitu sebesar $100 \%$.

Berdasarkan tabel 2 dapat diketahui tentang tingkat pengetahuan remaja putri tentang anemia pada remaja di SMA Negeri 1 Marga pada kategori pengetahuan baik yaitu sebanyak $88,3 \%$, pengetahuan cukup yaitu sebanyak 11,7\%. Pada kategori pengertian anemia paling banyak yaitu $89,8 \%$, pada kategori tanda-tanda anemia yaitu sebesar 93,4\%. Pada penyebab anemia paling banyak pada kategori cukup yaitu sebanyak $38,0 \%$, pada dampak anemia paling banyak dalam kategori baik yaitu $44,5 \%$. Pencegahan anemia paling banyak pada kategori baik yaitu sebesar 93,4\%, dan pada penatalaksanaan anemia yaitu paling banyak sebesar 92\% pada kategori baik.

Tabel 1 Distribusi frekuensi karakteristik responden berdasarkan tingkat pengetahuan tentang anemia pada remaja di SMA Negeri 1 Marga

\begin{tabular}{lll}
\hline Karakteristik responden & n & \% \\
\hline Kelas & 64 & $46,7 \%$ \\
XI & 73 & $53,3 \%$ \\
XII & & \\
Umur & 42 & $30,7 \%$ \\
16 tahun & 70 & $51,1 \%$ \\
17 tahun & 25 & $18,2 \%$ \\
18 tahun & & \\
Pekerjaan Orang Tua & 116 & $84,7 \%$ \\
Tidak PNS & 21 & $15,3 \%$ \\
PNS & & \\
Penghasilan Orang Tua & 49 & $35,8 \%$ \\
$<$ UMK & 88 & $64,2 \%$ \\
$>$ UMK & & \\
Tempat Tinggal & 137 & $100 \%$ \\
Rumah & & \\
Sumber Informasi Tentang Anemia & 57 & $41,6 \%$ \\
Tenaga Kesehatan & 24 & $17,5 \%$ \\
Guru & 56 & $40,9 \%$ \\
Internet & & \\
Mitos Tentang Anemia & 137 & $100 \%$ \\
Tidak Ada &
\end{tabular}


e-ISSN : 2614-5685

p-ISSN : 2614-5421

Tabel 2 Distribusi frekuensi Pengetahuan Remaja Putri Tentang Anemia Pada Remaja di SMA Negeri 1 Marga

\begin{tabular}{lll}
\hline Pengetahuan Remaja Tentang Anemia & n & $\mathbf{\%}$ \\
\hline Pengertian Anemia & & \\
Baik & 123 & $89,8 \%$ \\
Cukup & 11 & $8,0 \%$ \\
Kurang & 3 & $2,2 \%$ \\
Tanda-tanda Anemia & & \\
Baik & 128 & $93,4 \%$ \\
Kurang & 9 & $6,6 \%$ \\
Penyebab Anemia & & \\
Baik & 34 & $24,8 \%$ \\
Cukup & 52 & $38,0 \%$ \\
Kurang & 51 & $37,2 \%$ \\
Dampak Anemia & & \\
Baik & 61 & $44,5 \%$ \\
Cukup & 54 & $39,4 \%$ \\
Kurang & 22 & $16,1 \%$ \\
Pencegahan Anemia & & \\
Baik & 128 & $93,4 \%$ \\
Cukup & 8 & $5,8 \%$ \\
Kurang & 1 & $0,7 \%$ \\
Penatalaksanaan Anemia & & \\
Baik & 126 & $92 \%$ \\
Cukup & 11 & $8 \%$ \\
Pengetahuan Remaja Tentang Anemia & & \\
Baik & 121 & $88,3 \%$ \\
Cukup & 16 & $11,7 \%$ \\
Kurang & 0 & $0 \%$ \\
\hline
\end{tabular}

Pengetahuan adalah hasil "tahu" dan ini terjadi setelah orang melakukan penginderaan terhadap suatu objek tertentu. Penginderaan terjadi melalui panca indra manusia yakni, indra pengelihatan, pendengaran, penciuman, rasa dan raba. Sebagian besar pengetahuan manusia diperoleh melalui mata dan telinga. Pengetahuan atau kognitif merupakan domain yang sangat penting untuk terbentuknya tindakan seseorang (Notoatmodjo, 2011).

Salah satu pengetahuan yang harus dimiliki oleh remaja putri yaitu pengetahuan tentang anemia. Anemia adalah suatu kondisi medis di mana jumlah sel darah merah atau hemoglobin kurang dari normal. Kadar hemoglobin normal umumnya berbeda pada laki-laki dan perempuan. Untuk laki-laki, anemia didefinisikan sebagai kadar hemoglobin kurang dari 13,5 gram/100 ml dan pada perempuan yaitu kurang dari 12,0 gram/ $100 \mathrm{ml}$ (Proverawati, 2011).

Remaja putri lebih rentan terhadap anemia, hal ini berkaitan dengan kondisi remaja putri itu sendiri yang mengalami masa haid (menstruasi). Saat remaja putri mulai mengalami menstruasi di masa puber. Dalam fase itu, zat gizi seperti zat besi, vitamin A dan kalsium sangat diperlukan. Akibat menstruasi pada remaja putri dapat kehilangan zat besi hingga dua kali jumlah yang dikeluarkan oleh remaja putra. Karena itu kebutuhan zat besi pada remaja putri adalah tiga kali lebih besar dari remaja putra untuk mengembalikan kondisi tubuhnya ke keadaan semula untuk menggantikan darah yang keluar pada saat menstruasi (Wikipedia, 2014).

Menurut Proverawati (2011), pencegahan yang dapat dilakukan pada anemia antara lain mengkonsumsi bahan makanan sumber utama zat besi seperti daging, sayuran 
berwarna hijau sesuai kebutuhan, melakukan tes laboratorium untuk mengetahui kualitas sel darah merah (hemoglobin), harus diyankinkan bahwa masukan zat gizi yang kurang dari yang dibutuhkan akan berakibat buruk bagi pertumbuhan dan kesehatan, istirahat yang cukup dan kebiasaan hidup sehat.

Hasil penelitian tingkat pengetahuan remaja putri tentang anemia pada siswi kelas XII dan XI di SMA Negeri 1 Marga pada kategori pengetahuan baik sebanyak 121 responden $(88,3 \%)$, dan pengetahuan cukup sebanyak 16 responden $(11,7 \%)$.

Menurut Mubarak (2012), faktor -faktor yang mempengaruhi pengetahuan yaitu pendidikan, pekerjaan, umur, minat, pengalaman, kebudayaan lingkungan sekitar dan informasi. Umur mempengaruhi pengetahuan, dengan bertambahnya umur seseorang akan mengalami perubahan aspek fisik dan psikologis (mental). Secara garis besar, perubuhan fisik terdiri atas empat kategori perubahan yaitu perubahan ukuran, perubahan proporsi, hilangnya ciri-ciri lama dan timbulnya ciri-ciri baru. Perubahan ini terjadi karena pematangan fungsi organ. Pada aspek psikologis atau mental, taraf berfikir seseorang menjadi semakin matang dan dewasa.

Anemia memiliki dampak yang membahayakan pada remaja, dampak tersebut antara lain terganggunya pertumbuhan dan perkembangan, menurunkan fungsi dan daya tahan tubuh serta terganggunya fungsi kognitif, menurunnya produktifitas remaja, komplikasi kehamilan dan janin pada saat hamil (Yulivantina, 2016), tingginya Prevalensi anemia gizi besi pada remaja putri disebabkan oleh kebutuhan nutrisi yang tidak terpenuhi yang diakibatkan kebiasaan makan yang salah, tidak teratur dan tidak seimbang dengan kecukupan sumber gizi yang dibutuhkan tubuh seperti asupan energi, asupan protein, asupan karbohidrat, asupan lemak, vitamin $\mathrm{C}$ dan yang terutama kurangnya sumber makanan yang mengandung zat besi, dan asam folat. Selain faktor tersebut remaja puteri mengalami menstruasi setiap bulannya dan sedang dalam masa pertumbuhan sehingga membutuhkan asupan zat besi yang lebih banyak sehingga remaja putri memiliki risiko lebih besar untuk menderita anemia dibandingkan dengan remaja putra.

Pemerintah Indonesia telah melakukan upaya penanggulangan anemia remaja melalui strategi antara lain suplementasi besi, pendidikan gizi dan fortifikasi pangan. Program suplementasi yang dilakukan pemerintah adalah Pencegahan dan Penanggulangan Anemia Gizi Besi (PPAGB) dengan sasaran kelompok anak sekolah menengah. Program bagi remaja putrid dilakukan melalui promosi dan kempanye melalui sekolah secara mandiri dengan cara suplementasi zat besi dosis 1 tablet seminggu sekali minimal selama 16 minggu, dan dianjurkan minum 1 tablet setiap hari selama masa haid (Kemenkes RI, 2011).

Selain upaya tersebut perlu dilakukan upaya untuk meningkatkan pengetahuan remaja putri tentang gizi melalui pendidikan dan kampanye gizi menggunakan metodemetode yang menarik bagi remaja, pengetahuan tentang gizi yang kurang menyebabkan sebagian remaja tidak memahami apakah makanan sehari-hari yang dikonsumsi sudah memenuhi syarat menu seimbang atau tidak, dengan meningkatkan pengetahuan remaja tentang nutrisi dapat dijadikan tahap awal agar remaja mau dan mampu memilih konsumsi makanan yang baik bagi tubuhnya.

\section{Simpulan}

Simpulan dalam penelitian ini yaitu:

a. Tingkat pengetahuan remaja putri tentang anemia pada remaja termasuk dalam kategori baik yaitu $88.3 \%$

b. Tingkat pengetahuan remaja putri tentang pengertian anemia termasuk dalam kategori baik yaitu $89,8 \%$

c. Tingkat pengetahuan remaja putri tentang tanda-tanda anemia termasuk dalam kategori baik yaitu 93,4\%

d. Tingkat pengetahuan remaja putri tentang penyebab anemia termasuk dalam kategori cukup yaitu 38\% 
e. Tingkat pengetahuan remaja putri tentang dampak anemia termasuk dalam kategori baik yaitu 44,5\%

f. Tingkat pengetahuan remaja putri tentang pencegahan anemia termasuk dalam kategori baik yaitu 93,4\%

g. Tingkat pengetahuan remaja putri tentang penatalaksanaan anemia termasuk dalam kategori baik yaitu $92 \%$

\section{Referensi}

Arwin Arminiati, 2017. pengaruh poster pencegahan anemia terhadap perilaku dan kadar ibu hamil di wilayah kerja puskesmas baki sukoharjo. Fakultas ilmukesehatanUMS.http://eprints.ums. ac.id/51193/15/NASKAH\%20PUBLI KASI.pdf

Badan Penelitian dan Pengembangan Kesehatan Kementerian Kesehatan RI.. Riset Kesehatan Dasar (Riskesdas) 2013. Jakarta. 2013

Budiman (2016). Gambaran Tingkat Pengetahuan Tentang Anemia Pada Remaja Putri. Jurnal Ilmu Kesehatan. Sekolah Tinggi Ilmu Kesehatan Muhammadiyah Pekajang.

Depkes RI. (2017). Modul Pekatihan Pelayanan Kesehatan Peduli Remaja $(P K P R)$. Jakarta. Departemen Kesehatan RI.

Fikawati, S., Ahmad, S., Arinda., 2017. Gizi Anak dan Remaja. Depok: PT Raja Grafindo Persada.

Kemenkes RI, 2011. Upaya Penanggulangan Anemia Remaja di Indonesia. Jakarta. Badan Penelitian dan Pengembangan Kesehatan.

Kementrian Kesehatan RI. (2014). Riset Kesehatan Dasar. Jakarta. Badan Penelitian dan Pengembangan Kesehatan.

Mubarak, W. 2012. Promosi Kesehatan Untuk Kebidanan. Jakarta : Salemba Medika

Notoatmodjo, S. 2010. Metodologi penelitian kesehatan. Jakarta: PT. Asdi Mahasatya
Proverawati, A. 2011. Anemia dan Anemia Kehamilan. Yogyakarta : Nuha Medika

Suryani, D., Riska, H., Rinsesti, J., 2015. Analisis Pola Makan dan Anemia Gizi Besi Pada Remaja Putri Kota

Yulivantina, 2016. Hubungan Status Gizi dan Lama Menstruasi dengan Kejadian Anemia Pada Remaja Putri di SMA Muhammadiyah 7 Yogyakarta. 